\title{
Uneasy settlements:
}

\section{$\underline{\text { Reparation politics and the meanings of money in the Israeli withdrawal from Gaza* }}$}

\author{
Shai M. Dromi ${ }^{\dagger}$
}

\begin{abstract}
Negotiations about reparations tend to take the language of interests and to deal primarily with monetary compensation for disadvantaged groups. In such proceedings, aggrieved claimants are likely to make a variety of claims about the use of money to represent their experience, ranging from demands for increased compensation to rejections of the entire process altogether. This article draws attention to the communicative functions of money in the reparation process. It claims that actors may grudgingly agree to attach a monetary value to what they hold sacred, but simultaneously strive to preserve their sense of self-worth and to elicit identification by raising moral critiques about the use of fiscal logic. To exemplify, the article focuses on the 2005 removal of Jewish-Israeli settlers from Israeli-occupied territories. It shows that settlers indeed demanded to be compensated fiscally for their lost property. At the same time, it shows that they proffered moral denunciations of the use of fiscal logic in representing their experience and offered alternate logics of evaluation in its stead. The settlers resisted shame and devaluation through such competing logics, demanding that the state reaffirm a positive and embracing relationship with them despite its decision to evict them.

This is the peer reviewed version of the following article: Dromi, Shai M. (2014) "Uneasy Settlements: Reparation Politics and the Meanings of Money in the Israeli Withdrawal from Gaza." Sociological Inquiry 84 (2): 294-315, which has been published in final form at http://onlinelibrary.wiley.com/doi/10.1111/soin.12028/abstract . This article may be used for non-commercial purposes in accordance with Wiley Terms and Conditions for Self-Archiving.

Keywords: Commensuration, cultural sociology, Jewish-Israeli settlements, reparations, restorative politics

\footnotetext{
* The author is indebted to Jeffrey C. Alexander, Eva Illouz, and Philip Smith for their invaluable input on this study in various stages. The author also thanks Annika Arnold, Kristian B. Karlson, Matthew Lawrence, Laura Rienecker, and Samuel D. Stabler, as well as the Yale University Supper Culture Club participants, for their close reading and insightful comments on previous versions of this article. The article greatly benefited from the comments provided by three anonymous reviewers at Sociological Inquiry.

${ }^{\dagger}$ Department of Sociology, Yale University, 493 College St., New Haven, CT 06511; shai.dromi@yale.edu .
} 


\section{Introduction}

Judicial and legislative actors increasingly take monetary redress to be an obvious way to compensate aggrieved individuals and groups (Porter 1994, 1995, Fourcade 2011). Social groups that were adversely affected by state policy thus find themselves having to encapsulate their experiences in succinct financial formulae. In these situations, we often find claimants making contradictory claims, on the one hand insisting that their grievances are beyond fiscal valuation, and on the other hand debating the specific amount and details of the proposed sum. While sociologists have been exploring restorative politics and compensation strategies for some time now (Maier 2003), we still know little about the communicative functions money plays in reparation debates. Studying the ways in which actors accept, reject, or demand money when faced with the paradox of assigning a concrete value to their abstract experience will teach us much about how they signify to themselves and to others the meanings social processes hold for them. This, in turn, will provide much insight into the ways groups perceive of their collective identities and their relations with the state and broader society once those relations are compromised.

There is much sociological work explaining why and how actors reject attempts to equate what they see as sacred with money (Espeland 1998, Espeland and Stevens 1998). However, sociologists have also pointed to the paradox that those objects that are considered priceless (e.g., children) will garner the highest compensation if lost (Zelizer 1985). This article would like to ask how is it, then, that claimants may participate in compensation proceedings while at the same time presenting them as pointless; that is, how is it that they simultaneously reject attempts to formulate monetary redress and at the same insist on being recompensed. 
It is tempting to collapse all arguments actors might raise under the umbrella of profit maximization, and to thus interpret the critiques claimants make as ways to gain further leverage and further gains. Indeed, much of the literature about contentious politics conceives of such social conflicts as conflicts about interests per se (Tilly 2008, Tilly and Tarrow 2007). However, the assumption that "interests", whatever they may be, are an intelligible and unified order of worth that underpins all demands actors make ignores the multiple beliefs about worth actors may harbor and employ when debating matters of public concerns (Swedberg 2005, Boltanski and Thévenot 2006). Approaching the topic through the prism of interests says little about the ways in which actors wish to be heard and understood, and about their desire to communicate to others the cultural meanings of their grievances (Alexander 2004, Breese 2011). The current study suggests that deliberations about compensation be seen as a cultural production in which actors explicate what the social arrangements and processes in question mean to them. This understanding will highlight the communicative roles of money in reparation politics, and explain how actors agree to participate in discussions about how to best compensate them while at the same time presenting their losses as incommensurable.

To observe such processes in action, this article analyzes the 2005 removal of approximately 9,000 Jewish-Israeli settlers from the Gaza Strip and the West Bank (an act commonly known as the "Disengagement"). It focuses on the ways the settlers negotiated with the Israeli Parliament's Finance Committee about the suitable form of compensation for them. The article asks how the settler representative formulated their claims and how they managed the contradiction between the fiscal evaluation of their relocation and the intricate meanings they assign to their residence in the settlements. The committee protocols reveal that the settlers indeed demanded to be compensated 
in full for their lost properties, and engaged in elaborate fiscal estimations of the expected costs of the move. However, they also show that the settlers cared deeply about explicating why no compensation would suffice, and that they mobilized an array of cultural logics for this purpose. Settlers proffered moral critiques of the Disengagement both by referring to their own community and individual concerns (e.g., by citing the incommensurability of the expected personal suffering) and by raising moral critiques of Israeli government and society (e.g., by speaking of a broken pact between the settlers and the state). In doing so, settlers drew on the cultural codes they believe to share with the general public - describing Israeliness, patriotism, fraternity, solidarity, and the like - in order to deconstruct the economic logic of compensation at hand. Balancing the parallel lines of discussion - of how much the relocation would cost and of whether compensation is at all possible-allowed settlers to preserve a sense of worth, while simultaneously seeking identification with their cause and appealing for reconciliation with the general public.

While the settlers have been at the center of a considerable scholarly debate, there is still a dearth of knowledge about the repercussions the Disengagement has had on their collective identity. Much of the existing research has not focused on their actual words and deeds as a data source but has rather turned to their published statements, religious teachings, and organizational strategies (Aran 1988, 1991, Lustick 1988, Shahak and Mezvinsky 1999, Peri 2011, Newman 2005). The dominant literature on the subject has focused on the economic, strategic, and geopolitical structural characteristics of the Israeli occupation. While this literature has been particularly important in examining the pernicious effects of the Israeli occupation on the Palestinian people and on the complicity of state institutions with the settlement project (Allen 2008, Kimmerling 1992, Swedenburg 1990, Zertal and Eldar 2007, Shenhav and Berda 2009, Li 2006), it has had less 
to say about the settlers' collective identity and about their experience of the socio-political processes underway in the region. Indeed, no discussion of the settlers can ignore the repercussions their project has had on the Middle East, as the devastating effects of the Israeli occupation have been well documented (Allen 2008). The current study seeks neither to convince the reader that the evicted settlers are as much a victim as the Palestinians nor to endorse the settlers' worldview. It does intend, however, to better our understanding of the meanings the Disengagement holds for them. Whether acceptable for other Israelis or not, their beliefs have concrete implications for Israeli politics and, by extension, for the entire region. Understanding how they may be reconciled with broader Israeli values may prove crucial if further withdrawals materialize.

The Israeli case has some unique characteristics that set it apart from most other groups involved in reparation proceedings. The settlers do not represent a historically oppressed group, but rather a group whose status has changed due to new state policies. As such, they are comparable to the Pieds-Noirs after French withdrawal from Algeria. Like the Pieds-Noirs, there is no ethnic or religious boundary dividing the settlers from the government, and like the Pieds-Noirs, they enjoyed considerable government support in the past. Historically discriminated and marginalized groups can be expected to have different starting expectations and strategies in similar settings. These differences notwithstanding, historically marginalized groups will likely draw on other, nationally-specific cultural codes they will see as shared with broader society, such as democracy, multiculturalism, or recognition, as they debate the adequacy of money in compensating them. The Israeli case is useful as it offers us a concentrated example of such a debate in a concrete institutional setting, providing a clear methodological example of how one might investigate such phenomena. While this study cannot offer policy recommendations based on this particular corpus 
of data, solutions that resonate with the way in which claimants perceive their own identity and with the form of social relation they would like to establish with the greater polity are more likely to be acceptable for them. Studies such as the current one will provide insight into the cultural meanings at play in reparation proceedings, which might serve as infrastructure for such solutions.

\section{Literature Review}

Current studies of reparations tend to focus on the effect and utility of various types of compensation for historically discriminated or oppressed groups (Rwelamira and Werle 1996, Atuahene 2011, Williams and Collins 2004). Such research understandably tends to see state expenditure in favor of the claimants as the core of reparation processes. Recent sociological studies of reparations have grown sensitive to the diverse types of claims and negotiations that comprise reparation politics and have expanded their scope to include cultural, legal, symbolic, and economic claims (Torpey 2006). While aware that multiple forms of group interests can coexist, current studies continue to assume that reparation politics amount to the expression and fulfillment of group interests. Such assumption emphasizes culturally-defined groups' preoccupation with their collective identity, but it devalues the ways such groups might engage with more abstract concerns for the wider polity.

And yet, recent culturally informed studies suggest that reparation politics involves a further, communicative dimension through which aggrieved actors strive to represent and project their experience as well as their hopes for their collective future to the state and to the public. Tanya Goodman's study of the Truth and Reconciliation Committee demonstrates that, in inviting victims of apartheid to share their accounts of oppression and misery, the committee sought to introduce a 
sharp break between South Africa's repressive past and multicultural future (Goodman 2009). That is, the testimonies served not simply the specific interests of formerly oppressed South Africans (e.g., in providing emotional relief), but were also a way to establish a common narrative about the nation's character and values. Similar insights come from Melissa Nobles'study of apologies, which, in her words, actors use "in ongoing efforts to reshape the meanings and terms of national membership" (Nobles 2008, 36). Reparation work is thus often conceived by the involved parties as having much to do with the shared social, institutional, and cultural infrastructure that allows for peaceful coexistence among social groups (Maier 2003, 295).

However, the communicative nature of reparation politics is confounded by the fact that the centerpiece of many deliberations of this kind is monetary compensation. The contentious role of money in social debates has been demonstrated by economic sociology, in studies of the culturally variable ways in which pricing and valuation processes are shaped (Zelizer 1985, Zelizer 2010, Polillo 2011, Carruthers and Espeland 1998, Velthuis 2005). Specifically, what actors may or may not accept as compensation has been shown to be highly contingent on their beliefs and ways of evaluation (rather than being a function of their objective interests) (Espeland 1998). The employment of market language to represent complex and, at times, grueling experiences can thus be expected to raise adamant objections about the use of money. Times of trial such as these, when actors are intensely occupied about the proper ways to evaluate an issue at hand, are particularly useful moments for cultural sociologists to study in detail what social processes mean to those actors (M. Lamont 2012). Their objections and critiques are themselves illuminating about how claimants wish for their situation to be understood and represented, and the forms of compensation 
(if any) they would entertain. They demonstrate what Zelizer (Zelizer 2010) refers to as relational work, which denotes the ways actors use money to reaffirm or reconfigure their social relations.

Debates over monetary compensation are particularly revealing because they bring together what may, at first glance, be perceived as three disparate motivations. The first is, predictably, the pragmatic motivation to have whatever financial damages were sustained recompensed in full. The second is the desire to maintain a group sense of self-worth and dignity in face of adverse conditions through "boundary work" (M. Lamont 2000), which involves the construction of hierarchies between one's group and others and by emphasizing distinctness and moral superiority. Reparation debates place aggrieved groups at a specific danger of being stigmatized as having been "bought out" of their true commitments if they accept compensation all too easily (Wherry 2008), and such reparatory boundary work is to be expected in response. The third motivation is group members' wish to perform their suffering to others and to have other believe and identify with their experience (Alexander 2004). To do so, actors draw on scripts, symbols, and tropes they assume to be salient for their audiences (e.g., state actors, the media, uninvolved viewers), constructing elaborate narratives in an appeal to the moral frameworks they believe to be shared in their societies. The ultimate aim of such performances is to render the interaction between performer and viewer (or, in this case, between claimant, state, and public) meaningful and to lay out possibilities for new and different social relations between them.

The next sections will examine how the outlined processes unfold in situ. Following a brief historical overview of the Disengagement and a methodological note, the article will turn to the debates over the compensation of the evicted Jewish-Israeli settlers. The analysis will demonstrate 
how financial considerations, boundary work, and performance intertwine in debating how one might compensate for such relocation.

\section{Historical Context}

Jewish Israeli settlers began to migrate to the Israeli-occupied West Bank and Gaza Strip in the mid-1970s. This migration was initially motivated by religious belief, as religious-nationalist actors interpreted the Israeli capture of these lands as divine intervention and believed their settlement project to help bringing forth salvation (Aran 1988). Most Israeli settlements were rural and communal, and they faced repeated legal challenges and oscillating public support. In subsequent decades, the religious settlers were joined by secular ones, who found in the occupied territories cheap housing and rural lifestyles within commuting distance of Jerusalem and Tel Aviv. By the early 1990s the religious promise of salvation by way of settlement receded to the background and was replaced by a set of nationalistic explanations for the presence of Jewish Israelis in these regions. This discursive shift made the project more accessible to secular Jews who were often deterred by the messianic justifications for the settlements (Aran 1991, Taub 2010). Despite increasingly violent clashes with the Palestinian neighbors, allegations of illegal occupation and settlement, questionable public approval rates and self-contradictory government policies, the Jewish population in these territories climbed substantially in the following decades ${ }^{1}$.

The Gaza Strip, the main site of the Disengagement, spans a mere 140 square miles along the south-western coast of the country. On the eve of the Disengagement the population was estimated to be approximately 1,325,000 Palestinians and 8,500 Israelis living in 21 settlements, collectively referred to as Gush Katif (Matza, Ravid and Stern 2010). Most were rural townships, and only two 
exceeded 1,000 residents (Butler 2009). Four additional settlements were located in secluded parts of the West Bank and faced severe security challenges. In 2003, as peace negotiations between the Palestinian Authority and Israel were at a standstill, Prime Minister Ariel Sharon announced his intention to withdraw unilaterally from these areas and to relocate the settlers from those 25 settlements. The aims of this plan were mainly minimizing contact between Palestinian and Israeli populations, reducing the number of Palestinian civilians under direct or indirect Israeli responsibility, and ensuring a Jewish demographic majority under Israeli sovereignty (Israel Govt. Secretary 2004), as public concern with the high Palestinian fertility rate was growing. The Disengagement, then, was presented as a pragmatic solution to a dead-end situation-a solution which was for much of the Israeli public undesirable but inevitable (Matza, Ravid and Stern 2010).

This was not the first Israeli withdrawal, as similar challenges emerged in 1982 when Israel withdrew from the Sinai Peninsula, and yet the Disengagement was the largest and most complicated withdrawal in Israeli history. The long duration of Israeli presence in these territories allowed close knit Jewish communities to grow in Gaza and Samaria, and for support for the settlements to become a staple of Israeli right-wing and religious-nationalist popular politics (Feige 2009). Ensuring the cooperation of the affected residents and their supporters was thus among the top priorities for the government in preparing for the Disengagement.

\section{Determining Compensation}

The task of determining compensation for the relocated citizens further challenged both legislators and claimants for several reasons. First, in addition to the anticipated personal suffering involved in the removal of any population from its home and community, the more general idea of an Israeli 
withdrawal clashed with the theology to which many of the potential evictees subscribed. Religious settlers were shocked by the state interference in the project they saw as sacred (Dalsheim 2011, Susskind, et al. 2005). Secular settlers were still characterized by devoted nationalism and were taken aback by the drastic change in state policy, led by the conservative prime minister and government who were, until then, their strongest allies. The settler movement's failure to mobilize the wider public in Israel, who mostly opted for the role of "interested bystanders" (Feige 2009, 263), added insult to injury. As a result, a general hostility toward the government proliferated among settler groups, making negotiation with its institutions particularly difficult.

Second, a commonly expressed belief among religious settlers was that the Disengagement plan would simply not materialize: either by way of divine intervention or, more directly, by a massive public denunciation and resistance, the plan was expected to fail (Billig 2005). This belief moved many of the settlers to continue their lives as usual, planting new crops, redecorating their homes, and planning future activities for their settlements regardless of the news of their upcoming demolition and without serious preparation for relocation (Hirschberger and Ein-Dor 2006).

Third, the Finance Committee is by definition authorized to speak in terms of budget, and cannot ponder about the ethical underpinnings of the law itself. Despite the fact that the bill had not yet been approved in parliament, such discussions required the participants to treat the proposal very much as a concrete one, and ask not whether it would materialize, but how. Since some of the participating members of parliament were themselves settlers or sympathizers, their office required them to simultaneously oppose the bill and help move it forward. Thus, at the same time that the 
settlers were denouncing the Disengagement plan, many of them were asserting that it would not materialize, and at the same time that they were doing both they were invited to plan for the day after.

\section{Methods}

In order to study the compensation negotiations, 30 protocols of the meetings of the Finance Committee and its subcommittees concerning the Disengagement were closely read. These protocols document all meetings that took place between December 2004 and February 2005 and dealt with the amendments to the proposed bill outlining the withdrawal and the compensations. The committee was officially comprised of 26 members, out of whom 13 represented proDisengagement parties, 11 represented dissenting parties, and two represented a neutral party ${ }^{2}$. Three of the members were themselves settlers, one of whom resided in the Gaza Strip and was thus to be directly affected by the act. The committee subpoenaed the relevant officials in the Prime Minister Office and other state authorities to provide clarifications or to discuss the feasibility of various proposed changes. Most important for our study, though, is that it invited numerous residents of the affected settlements to speak before them: local politicians, industrialists, farmers, lawyers, professionals, and other locals who agreed to appear ${ }^{3}$.

All relevant protocols were accessible on the official parliament website, and were closely read and coded using Atlas.ti. Each code consisted of a distinct mode of evaluation a speaker employed in order to assess the worth of each aspect of the relocation. Attention focused on the occasions in which actors disagreed on the very form of evaluation that was appropriate for the matter at hand, and several specific questions guided the analysis: what did they find to be relevant factors to cite? Was the discussion about the amount of compensation or its quality? Was compensation 
considered unacceptable because of the emotional anguish involved? Was it because of the ideological meanings of withdrawing from these territories?

The claims were then organized according to the principle of equivalence they expressed: on the one hand were the arguments that operated on the logic of the market and referred to the sum of money to be allotted to the settlers, while on the other hand were the arguments that rejected this logic and cited various intangibles it fails to grasp. The latter arguments-expressing incommensurability - were then arranged according to the way by which the speakers communicated precisely what was incompatible with monetary logic and how. Here, the key division was between those claims that cited the settlers' own distinctiveness as the central problem and those claims that were oriented toward Israeli society and government and sought to elicit identification and solidarity. The analysis will explicate each of these logics in turn.

First, it will demonstrate that - paradoxically in light of their denunciation of the Disengagement plan — the settlers cared much about receiving generous monetary compensation not only for their assets but for a variety of costs associated with the move and the relocation. However, this was not simply a negotiation about money per se, but also an intricate negotiation of the symbolic meanings the state is assigning the settlers by way of its financial plan for them. Second, the analysis will show that the debates over the fiscal value of the relocation were bracketed by a denial of the very commensurability of the move, as settlers emphasized their exceptional relation to the land and their way of life. Through intense boundary work they sought recognition and affirmation of their unique character. Third, it will demonstrate that the settlers attempted to appeal to a sense of solidarity between themselves and the general public (vis-à-vis the state). The settlers drew on cultural codes they believed they share with the public, demanding that the state signify that it 
accepts and embraces them as an integral and valued part of the Zionist movement. These three logics were not chronological (that is, the settlers did not use one, and then turn to another when their efforts failed). All three were present simultaneously, together comprising the settlers' struggle to make sense and meaning out of this seemingly bureaucratic process, and to articulate their perceived and desired relations with the state.

\section{Findings}

\section{Commensurable Claims}

The settlers initially rejected any cooperation with the Prime Minister Office in drafting the bill and discussing what proper recompense might be. However, as soon as the Disengagement Plan began to move forward in legislative channels, representatives of the affected residents of Gaza and Samaria became anxious to appear at the Finance Committee proceedings and to present their claims.

Receiving little cooperation from settlers or their representatives, Prime Minister Office officials, charged with drafting the bill, had worked under the assumption that their task was chiefly estimating the costs of relocating the affected population. While the initial outline of the plan stated that the bill should allow for the option of resettling the evicted together so as to preserve their communities and to thus soften the blow, this aspect remained unaddressed and was subsequently buried in bureaucracy (Matza, Ravid and Stern 2010). The government forwarded the bill to parliament for approval on June 4, 2004, stating — despite the meager settler cooperation in drafting the bill — that it still sees "great importance in communicating with the affected population about various matters pertaining to the implementation of the plan, including...the compensation" (Israel 
Govt. Secretary 2004, Section 2, Appendix 3) ${ }^{4}$. As part of the legislative process, the bill was assigned to the Finance Committee in order to review the proposed compensation of the evicted residents.

Unlike the Prime Minister Office, the parliamentary committee worked directly with settler representatives, who perceived of parliament as a more balanced site in which to voice their concerns. A sub-committee toured selected settlements in Gaza, met with residents, and heard their complaints in addition to those civilians who testified before it in parliament. This body specifically saw its role as amending a then-insensitive law. As the chairman later testified, the draft looked to him "like a corporate profit and loss statement, rather than a bill intended to deal with real people” (Matza, Ravid and Stern 2010, 104).

At face value, much of the discussion was dominated by the recognition by all sides that the lost properties and the sources of income should be fully compensated. Not only were these factors considered, but the projected costs of relocating, seeking employment, and readjusting to new surroundings were also included. The expected personal hardships of the relocation were associated with costs of psychologists and special child care that would be required in its aftermath. To this end, a battery of experts was summoned to provide cost and value estimates, and business and home owners were similarly asked to evaluate the various amendments proposed. While bitter disputes did arise, many of them were concerned with questions of how much and what should be compensated for, rather than whether they can be compensated in the first place.

By describing the proposed sums as insufficient, settlers were not only referring to the actual costs involved in their relocation. They also employed fiscal logic in evaluating the state's own response 
to their plight. They were troubled, for example, by the differential land pricing they would face when relocating, as land and housing in the Occupied Territories were considerably cheaper than in equivalent relocation sites. Based on this and other such concerns, the bill was labeled as criminal: "This bill is a robbery. Beyond the political issues, it robs people of their assets...someone from my settlement said...'not only are they expelling me...they're also not giving me what already belongs to me" (Tzvi Hendel, 2/3/05). A direct link was thus made between the value the state assigns to the settlers and the amount of money it is willing to expend on their behalf: "All these years I worked day and night...for this country, because I love this country and I want to bring money into its treasury... besides my business I raised two sons who serve today in the army... after all the years that I worked honestly for the country and never took a dime, this is what I get" (Avraham Vitaney, 4/1/05).

\section{Incommensurable Losses}

If we have just seen how the settlers employed fiscal logics in debating proper commensuration, the next section will demonstrate how they simultaneously did the opposite, first by emphasizing how their unique identity cannot be captured by fiscal reasoning, and second by raising critiques about the moral implications of the changing state attitude toward them.

Maintaining Boundaries. In discussing what they see as the special characteristics of their society, the settlers engaged in considerable boundary work. Such preoccupation with collective identity can be expected when a group sees itself as compromised by adverse social conditions (Alexander 2004, Eyerman 2004). The settlers concentrated on several key features of their self-perception, which they presented as standing in the way of any fiscal compensation. 
First, the settlers highlighted the uniqueness they saw in their specific region and the deep emotional ties they have developed with it over the years. The prospect of relocating was sharply differentiated from a regular move: settlers emphasized having personally built their homes and towns, dedicating their lives to their settlements and caring deeply about their communities. A specific concern had to do with permanent sites that would be left behind, such as graves and synagogues: "My son gave his life for the People of Israel, and he's buried in Gush Katif, and this is the only memory I have of him..." (Yitzhak Meiron, 2/2/05). Another speaker said that "[T]here are things that you [secular people] will never understand. A new place may have 100 synagogues but if I live there I won't be able to pray at any of them...I won't have...the synagogue that I built with my ten fingers" (Nissim Dahan, 2/2/05). The settlers spoke of their certainty that the Disengagement will cause permanent emotional harm to their families and themselves.

Second, the settlers cited the strong community ties, essential to their collective character (Billig 2005), which they believed they will soon lose. Representatives referenced "the special environment, the people, the warm ties that have been created...[the] open people with open hearts" (Avner Shimoni, 2/2/05). The Disengagement was portrayed not only as a forced eviction of the settlers from their homes, but also as the impending dissolution of their community. For this reason, a recurring claim expressed the desire to remain together, as a community, after the Disengagement and to be allocated a similar region for their resettlement. "The minimum [they could do] is to relocate communities as they are, because the value of the homes and lands are one element, but the communities, the way of life, and the friendships among the residents are often worth much more" (Nissan Slomianski, 12/8/04). 
Third, the settlers referenced the innovative farming and industrial initiatives they established in the region, ones which are unique to their region and would be unlikely to succeed elsewhere. The fact that Gaza is "the only place in the country where [specific crops] are grown" (Gadid Representative, 24/1/05) was part and parcel of the land's sacrality for these speakers. As one of them explained, "agriculture is not just a business, it's a way of life, and it roots you to your plot" (Ilan Lefler, 2/1/05). The fate of their industries also had to do with their sense of autonomy and dignity: "I was raised to be independent,...to take chances, to develop, to invest, and today I find myself paralyzed" (Kobi Cohen, 1/4/05).

Particularly objectionable was the proposed section that would grant additional compensation for residents who would leave voluntarily (and would thus spare the government the costs of a forced eviction). The bill was accused with "denying the settlers the right to cry, to tear their clothes [a Jewish mourning custom] outside their homes...giving them pennies for a forced eviction, on the condition that they behave nicely" (Benyamin Alon, 1/30/05). The idea that public expenditure had anything to do with the settlers' pain was presented as ludicrous. This aspect of the bill was interpreted as an attempt to divide communities over the question of voluntary relocation.

As this section demonstrates, the settlers valuated the Disengagement as a community disaster, even as they were speaking of its financial value. While the idea of compensation was painful for the individual settlers, they did not balk at discussing property worth and costs of individual relocation. But when presenting the implications for the settlers as a society, a monetary compensation was unthinkable. Returning once and again to the ways in which they-as a society—are different by explicating their symbolic boundaries, the settlers also confronted the 
committee with justifications as to why no monetary compensation will address their sense of collective trauma.

Performing Solidarity. A central aspect of the settlement project is its self-identification with the Zionist project (Feige 2009, Aran 1991). For the settlers, the government and public approval of the Disengagement devalued their citizenship: from being the avant-garde of Israeliness, they have become law-breakers, fanatics, and potentially violent hoodlums in the public eye. The prevalent feeling among the settlers was that the state they hold to be sacred has abandoned them (Shor 2008). By speaking about what they believed they share with the general public and how they thought they contributed to its welfare the settlers sought to restore a sense of mutual trust, based on their perception of themselves as model citizens and of the state as the supportive and loved object of their endeavors. They did so in several ways.

First, settlers took pains to describe themselves as standing at the heart of Israeli consensus, leading Israeli society in building the country. One agriculturalist asked "to remind [the committee] that this is a group of settlers that the public calls 'salt of the earth'", building a project which is "chapter in our nation's history" (Eliezer Yaakov, 1/16/05). The speakers insisted on using the term mityashvim to denote settlers, rather than the more common term, mitnachlim: where the latter term usually refers to the West Bank and Gaza settlers (and is laden with connotations of political hawkishness and, to some extent, religious nationalism), the former is generally devoid of such connotations and bears reference to the $19^{\text {th }}$ and early $20^{\text {th }}$ century Jewish migration and settlement in what would become the State of Israel. By drawing upon what they identified as a consensual 
signifier, the settlers were tying themselves to the core of Israeli identity and representing their project as part and parcel of the Zionist one.

Second, settlers took pains to construe the settlement project as approved and supported by the general public, and to claim that public opinion has only recently turned against it. To this end, the settlers repeatedly claimed that previous governments have not only consented to the settlement project, but have actually endorsed and encouraged it: "There is no single house, no single nail in the settlements...that the state didn't want in place...the Prime Minister [Sharon] visited almost all of these place—visited, hugged, kissed..." (Tzvi Hendel, 1/19/05). Iconic left-wing political figures (arguably opposed to the settlements) were presented as inspirational ones for the settlers, as one settler claimed that the settlers have come to Gaza "following the call of Israel Galili and Yitzhak Rabin, RIP [senior Labor Party members]" (Avner Shimoni, 2/2/05). They strongly resisted the counter-argument that they had known that their residence in these territories was temporary. The implication for them was that "there is an agreement that the state made, and then broke, with the settlers," and that the public has chosen to disregard the long years in which the settlers labored "in the nation's service" (Tzvi Hendel, 1/16/05).

Third, the settlers posited that, not only did they establish the settlements at the state's mission, but they continued to faithfully serve the public by establishing industries and serving in the military. They emphasized their financial contribution to the public ("I work and provide work for almost 30 residents of Gush Katif and others beyond it. I pay salaries and taxes on time and I have no debts" (Yossi Noyman, 1/18/05)) and even what they saw as benign relations with the Palestinian neighbors ("We had wonderful relationships with the Palestinians...I myself employed 
570 Palestinian workers" (Kobi Cohen, 1/4/05)). Intertwined with these claims were strong statements about the moral superiority of the settlers. One speaker went as far as to cynically claim that "it may be good for us as citizens of this state if the people of Gush Katif will be dispersed across the country, because they will raise the moral level of the community wherever they may go" (Naphtali Yonah, 2/1/05).

Military service was a particularly recurrent theme, as settlers accentuated their strong relation to the Israeli Defense Force in their self-presentation. Settlers often introduced themselves by way of citing devoted military service: "I have three children — a son who is an officer in the military (I myself am retired from the military), a daughter who was just discharged and a daughter...who is about to fulfill her duty..." (Reuven Tabib, 2/1/05). Military service is a salient code in Israeli society, and is considered among the highest indicators of good civics, expected of most Jewish men and women (Peled 2008). As such, it was a code by which speakers appealed to their audience in search of identification. They similarly highlighted their victimization by war and terrorist attacks: "someone [in our settlement] was murdered...someone was shot...someone's car was hit by a Molotov cocktail... families were ruined" (Eliezer Nudelman, 2/1/05). Another resident continued: "My neighbor's son...fell in 1977 in a naval commando operation in Lebanon. My settlement's rabbi was murdered... and two other residents were also murdered over there..." (Yaki Yizraeli, 2/1/05). Like military service, bereavement is an extremely powerful code in Israeli discourse, and the families of the casualties of national wars and conflicts are considered to be one of the most valorized groups in Israel (Handelman and Katz 1990, Vinitzky-Seroussi and Ben-Ari 2000). For this reason, returning to the casualties the settler community has sustained not only sets 
them apart because of their sense of sacrifice, but also underlines the common denominator between themselves and the general Israeli public.

In the previous section we saw the settlers communicate they ways in which they feel unique; in this section we saw them convey what they feel they share with the general public. By way of doing so, they explicated the key to their soured relations with the state. Their complaint was that their years of good citizenship — of service for the country, of deep love towards the state and the public - were dismissed, turning them from law-abiders to criminals, from hard-working to freeloading, and from civil servants to public enemies. The recurring accusation was that the Disengagement plan, and the accompanying public approval, has turned the settlers "into violent people who are socially undesirable and into a liability on the taxpayer" in the public mind (Bentzi Liberman, 2/1/05). The act was presented as intended "to push the settlers to extreme acts" so that "when emotions will erupt they will be blamed with extremism, they will be portrayed as violent people" (Nissim Dahan, 2/3/05). A psychologist, herself a resident of Samaria, warned about potential traumatization if the general public will "not receive them with love, with recognition (in the simplest sense of acknowledging the suffering that they experienced, and in acknowledging that they have been through this suffering for the good of the whole society, and not for themselves)". She suggested that "tremendous effort should be directed towards a campaign...that would act against the image that is developing, an image of war-mongers, of freeloaders, of violent settlers" (Miryam Shapira, 2/1/05). Numerous others joined in presenting themselves and others in their regions as exemplary citizens, to the contrary of what they saw as "the stigma that people are trying to pin to the average settler in Gush Katif”' (Tzvi Hendel, 1/3/05). 
While a section of the bill granted compensation to settlers based on their seniority in their settlement, as an attempt to encompass all such claims, it was contested as inadequate. In attempting to reach a parsimonious solution, the government chief of staff explained: "[W]e have to come to terms with the irrational claims in this section... I think it is a good idea to look at all of these immeasurable and psychological factors... and to try to achieve something adequate that takes into account all of them. It would greatly shorten these proceedings if we do" (Ilan Cohen, 1/3/05). But such a simplifying solution was exactly not what the claimants sought. Their recurring wish was that regardless of the costs, the state would take full responsibility in caring for them in the future: "I don't want money; I want the state to commit that if in the next twenty years I will need to provide mental health care for my family, for my children, that it would not be out of my pocket. I don't want money, I want a commitment that if someone's mental system will collapse, we'd know they'll be taken care of" (Tzvi Hendel, 2/3/05). Restoring trust between the nation and the settlers was thus presented as crucial. Speakers wanted to be assured that the government will "tell the residents that there are infrastructures in place for them" rather than simply provide them with money (Nissan Slomianksi, 12/8/04) and that the bill be "fair, honest, embracing, supportive, even if it costs \%101" (Nissim Dahan, 2/3/05), thereby reestablishing a positive relationship between settlers and the state.

\section{Discussion}

The settlers' endeavors at the Finance Committee demonstrate the cultural work involved in reparation politics. While the settlers certainly insisted on a generous compensation for their properties and their relocation expenses, their claims were undergird by their desire to avoid shame and by the wish for their collective interaction with the state to be meaningful (rather than mundane 
and bureaucratic). In this, they strived to have their audience both recognize their unique cultural identity and reaffirm their importance for the state and the Israeli public.

For the student of reparation politics, the shift of focus from the underlying interests that might guide such proceedings to the cultural work involved in compensation debates will shed much light on the ways in which groups experience adverse social processes. Reframing the study of reparation will draw attention to the multiple concerns a group seeks to address when engaging with the question of compensation. While the wish to receive monetary compensation should not surprise us, the fact that such wish is bracketed by broader questions of what accepting such compensation would mean is an important insight that should be taken into account in future studies of restorative politics.

The multiple claims raised by the settlers demonstrate the capacity to voice objections using one logic (such as civic virtue), and then to turn to another logic (such as market worth) in debates about the common good. As Boltanski and Thévenot (1999) claim, actors may ultimately reach a compromise despite the multiple incompatible logics at play by temporarily putting aside their differences and reserving the right to revisit the matter at a later point. Actors may thus agree to accept a form of compensation they generally see as unfair (or, at the very least, they may agree to let matters rest), without relinquishing their broader view of the situation as unjust. The cultural strategies demonstrated by the Israeli case help groups agree to such compromises while at the same time clarifying - to themselves and to others - that matters were not fully resolved. Since resentment is a powerful moral protest, generally adopted once other means of contention are impractical or unavailable (Brudholm 2008), remaining indignant allows a party to accept 
compensation without discarding its moral denunciation. This, in turn, keeps the grievance alive and opens the way for future boundary work based on a shared sense of past mistreatment and unfairness.

For this reason, allowing for a relatively efficient and smooth compensation process is particularly undesirable for such a compensated group as it bears with it the potential humiliation of having relinquished what was previously a deep commitment. As Wherry claims (2008), one's fiscal selfmanagement is often a source of significant stigmatization through social labels such as "hasty", "miserly", or "gullible". Actors will indeed strenuously resist attempts to put a price on what they see as fundamental to their identities (Espeland 1998, Raz 1986), but when left with no choice, actors will at the very least make the process grueling and cumbersome by representing the multiple levels in which they find such commensuration unacceptable so as to avoid such stigma.

However, beyond the attempt to maintain their dignity, collective claimants will also appeal to the values they believe they share with the greater polity so as to describe the form of future existence they would like to uphold in their societies. While the specific emphases placed by the settlerson solidarity, on patriotism - emerge from their own culture and history within the State of Israel, culturally informed studies of other reparation processes will reveal the cultural assumptions of other groups and the ways in which possible shared futures are imagined in other national contexts. Other groups may invoke promises of democracy, of equality, or of cultural recognition they see as binding both to their own society and to their national culture, and make demands similar in form to those made by the settlers. Their belief that their own group and broader society shares a 
certain set of fundamental values that have been compromised will shed much light on the ways agreement and reconciliation can be achieved.

The findings also complement our empirical understanding of the ways the settlers see themselves, their project, and their place in Israeli society. Rather than proffering religious admonitions, and rather than engaging in belligerent, hawkish politics (as many existing studies would lead us to expect, e.g., Zertal and Eldar 2007), settlers made claims about the emotional anguish they experience and anticipate in being removed from their communities, in the business and agriculture they take pride in being torn away, and in the devaluation of what they see as exemplary citizenship. Despite the fact that the settlers are a diverse group, ranging from the religiously orthodox to the secular, they constructed a shared narrative of betrayal by the state, demonstrated in ways ranging from the loss of their industries on the secular side to the loss of synagogues and spiritual communal lifestyles on the religious side. Their shared desire that the spirit of the law would be generous and embracing is indicative of their more general expectations from the state. Indeed, beyond the committee's debates, alternative forms of compensation were suggested, such as an "ideological compensation", which would include the introduction of legislative acts and regulations in the spirit of the religious-Zionism prevalent among the settlers (Sheleg 2007). The logic of such alternative compensation was to allow the majority of the settlers to feel that they have contributed to Israeli society in ways other than establishing settlements.

While the relative absence of fundamentalism or political hawkishness in these specific protocols says little about whether or not many of the settlers believe in them, it tells us much about what they see as relevant when presenting their cause to the state and its agencies and ultimately about 
how they see their relations with Israeli society. Indeed, while scholars regularly invoke the connotation-laden category of "fundamentalism" in reference to the settlers (e.g., Lustick 1988), numerous policy papers published in the mid-2000s demonstrate that the settler "laity" had much more diverse stances, and tended to hold more moderate opinions than those represented by their leadership (Billig 2005, Schnell and Mishal 2005, Sheleg 2007).

Admittedly, one cannot generalize from these data about how the settlers as a whole felt and continue to feel about the Disengagement. Despite the diversity of the speakers the committee invited, the very act of appearing in parliament, even under protest, involved considerable selfselection and may have excluded those who harbored more vehement opposition to the withdrawal. However, the fact that the vast majority of the evicted settlers cooperated with the evicting forces and with the government distribution of compensations (Matza, Ravid and Stern 2010) suggests that the committee proceedings resonate with the beliefs held by the wider public in the settlements.

\section{Conclusion}

The debates and ensuing amendments to the law ultimately brought on mixed results. In the short term, the amendments to the bill substantially improved the compensation for lost property and costs of relocating. The section compensating settlers for the emotional hardship of relocating based on their seniority in their pre-Disengagement residence remained in place. The government attempted to allocate grounds for the settlers in the dunes to the north of the Gaza Strip, temporarily housing them in expanded trailers, so as to allow them to retain their communal way of life. However, a 2009 State Committee inquiry found the majority of those settlers still living in 
temporary residences, with many of them unemployed and in severe emotional distress (Matza, Ravid and Stern 2010). At the same time, a deepening alienation from the state evolved among various factions of the greater settler society. This radicalization has brought on progressively insistent attempts to settle in new parts of the West Bank, leading to violent clashes with the authorities (e.g., the Amona eviction of 2006). The long-term outcomes of the Disengagement have yet to unfold, and remain a topic for future research.

Debates about proper reparations are not confined to the specifics of a certain past or present complaint; they bring to light the ways actors interpret and criticize broader social processes that surround them, and they say much about how actors see their future coexistence as a society. While they often take the language of interests, they are irreducible to interests alone. A cultural sociological approach such as the one this study takes reveals much about what reparations might mean to the affected parties, and what sort of future they can envision together. As further evictions have occurred since the Disengagement, and as others may be yet to come, the understanding that alongside their complex value system and theology the settlers strive for inclusion will become increasingly pressing for Israeli society.

\section{References}

Alexander, Jeffrey C. "Cultural Pragmatics: Social Performance between Ritual and Strategy." Sociological Theory 22, no. 4 (2004): 527-573.

Alexander, Jeffrey C. "Toward a Theory of Cultural Trauma." In Cultural Trauma and Collective Identity, by Jeffrey C. Alexander, Ron Eyerman, Bernhard Giesen, Neil J. Smelser and Piotr Sztompka, 1-30. Berkeley, CA: University of California Press, 2004. 
Allen, Lori. "Getting by the Occupation: How Violence Became Normal during the Second Palestinian Intifada." Cultural Anthropology 23, no. 3 (2008): 453-487.

Aran, Gideon. A Mystic-Messianic Interpretation of Modern Israeli History: The Six-Day War as a Key Event in the Development of the Original Religious Culture of Gush Emunim. Vol. 4, in Studies in Contemporary Jewry, edited by Jonathan Frankel, 263-275. New York, NY: Oxford University Press, 1988.

Aran, Gideon. "Jewish Zionist Fundamentalism." In Fundamentalisms Observed, edited by Martin E. Marty and Scott R. Appleby, 265-344. Chicago, IL: Chicago University Press, 1991.

Atuahene, Bernadette. "Paying for the Past: Redressing the Legacy of Land Dispossession in South Africa." Law \& Society Review, 2011: 955-989.

Billig, Miriam. Settlers' Perspectives on the Disengagement from Gaza [Hebrew]. Jerusalem: The Floersheimer Institute, 2005.

Boltanski, Luc, and Laurent Thévenot. On Justification: Economies of Worth. Princeton, NJ: Princeton University Press, 2006.

Boltanski, Luc, and Laurent Thévenot. "The Sociology of Critical Capacity." European Journal of Social Theory 2, no. 3 (1999): 359-377.

Breese, Elizabeth Butler. "Claiming Trauma through Social Performance: The Case of Waiting for Godot." In Narrating Trauma: On the Impact of Collective Suffering, edited by Ron Eyerman, Jeffrey C. Alexander and Elizabeth Butler Breese, 213-236. Boulder, CO: Paradigm Publishers, 2011.

Brudholm, Thomas. Resentment's Virtue: Jean Amery and the Refusal to Forgive. Philadelphia: Temple Univ. Press, 2008.

Butler, Linda. "Gaza at a Glance." Journal of Palestine Studies 38, no. 3 (2009): 93-97. 
Carruthers, Bruce, and Wendy Nelson Espeland. "Money, Meaning, and Morality." American Behavioral Scientist 41 (1998): 1384-1408.

Dalsheim, Joyce. Unsettling Gaza: Secular Liberalism, Radical Religion, and the Israeli Settlement Project. New York, NY: Oxford University Press, 2011.

Espeland, Wendy N. The Struggle for Water: Politics, Rationality and Identity in the American Southwest. Chicago, IL: Chicago University Press, 1998.

Espeland, Wendy N., and Mitchell L. Stevens. "Commensuration as a Social Process." Annual Review of Sociology 24 (1998): 313-43.

Eyerman, Ron. "Cultural Trauma: Slavery and the Formation of African American Identity." In Cultural Trauma and Collective Identity, 60-111. Berkeley, CA: University of Calfornia Press, 2004.

Feige, Michael. Settling in the Hearts: Jewish Fundamentalism in the Occupied Territories. Detroit, MI: Wayne State University Press, 2009.

Fourcade, Marion. "Cents and Sensibility: Economic Valuation and the Nature of "Nature"." American Journal of Sociology 116, no. 6 (2011): 1721-77.

Goodman, Tanya. Staging Solidarity: Truth and Reconciliation in a New South Africa. Boulder, CO: Paradigm Publishers, 2009.

Handelman, Don, and Elihu Katz. "State Ceremonies of Israel: Remembrance Day and Independence Day." In Models and Mirrors: Towards Anthropology of Public Events, by Don Handelman, 191-233. Cambridge: Cambridge University Press, 1990.

Hirschberger, Gilad, and Tsachi Ein-Dor. "Defenders of a Lost Cause: Terror Management and Violent Resistance to the Disengagement Plan." Personality and Social Psychology Bulletin 32, no. 6 (2006): 761-769.

Israel Central Bureau of Statistics. Statistical Abstract of Israel No. 56. Jerusalem: Central Bureau of Statistics, 2005. 
Israel Govt. Secretary. Government Decision n. 1996. Jerusalem: Government Secretary, 2004.

Kimmerling, Baruch. "Sociology, Ideology, and Nation-Building: The Palestinians and Their Meaning in Israeli Sociology." American Sociological Review 57, no. 4 (1992): 446-460.

Lamont, Michèle. Money, Morals, and Manners: The Culture of the French and American Upper-Middle Class. Chicago: University of Chicago Press, 1992.

Lamont, Michèle. The Dignity of Working Men: Morality and the Boundaries of Race, Class, and Immigration. New York and Cambridge, MA: Russel Sage Foundation and Harvard University Press, 2000.

Lamont, Michèle. "The Study of Boundaries in the Social Sciences." Annual Review of Sociology 28 (2002): 167-195.

Lamont, Michèle. "Toward a Comparative Sociology of Valuation and Evaluation." Annual Review of Sociology 38 (2012): 201-21.

Li, Darryl. "The Gaza Strip as Laboratory: Notes in the Wake of Disengagement." Journal of Palestine Studies 35, no. 2 (2006): 38-55.

Lustick, Ian S. For the Land and the Lord: Jewish Fundamentalism in Israel. New York, NY: Council on Foreign Relations, 1988.

Maier, Charles S. "Overcoming the Past? Narrative and Negotiation, Remembeing, and Reparation: Issues at the Interface of History and the Law." In Politics and the Past: On Repairing Historical Injustices, edited by John Torpey, 295-304. New York and Oxford: Rowman \& Littlefield Publishers, 2003.

Matza, Eliyahu, Shimon Ravid, and Yedidia Z. Stern. "Report of the National Committee of Inquiry about the Treatment of the Gush Katif and Northern Samaria Evictees by State Authorities." Jerusalem, 2010. 
Newman, David. "From Hitnachalut to Hitnatkut: The Impact of Gush Emunim and the Settlement Movement on Israeli Politics and Society." Israel Studies 10, no. 3 (2005): 192-224.

Nobles, Melissa. The Politics of Official Apologies. Cambridge: Cambridge University Press, 2008.

Peled, Yoave. "The Evolution of Israeli Citizenship: An Overview." Citizenship Studies 12, no. 3 (2008): 335-345.

Peri, Yoram. "Land versus State: Israel and its Army after the Disengagement." Dissent 53, no. 1 (2011): 15-18.

Polillo, Simone. "Money, Moral Authority, and the Politics of Creditworthiness." American Sociological Review 76, no. 3 (2011): 437-464.

Porter, Theodore M. "Objectivity as Standardization: the Rhetoric of Impersonality in Measurement, Statistics, and Cost-benefit Analysis." In Rethinking Objectivity, edited by Allan Megill. Durham, NC: Duke University Press, 1994.

—. Trust in Numbers: the Pursuit of Objectivity in Science and Public Life. Princeton, NJ: Princeton University Press, 1995.

Raz, Joseph. The Morality of Freedom. Oxford: Oxford University Press, 1986.

Rwelamira, Medard, and Gerhard Werle, . Confronting Past Injustices: Approaches to Amnesty, Punishment, Reparation, and Restitution in South Africa and Germany. Durban: Butterworths, 1996.

Schnell, Itzhak, and Shaul Mishal. Uprooting and Settlers' Discourse: The Case of Gush Katif. Jerusalem: The Floersheimer Institute for Policy Studies, 2005.

Shahak, Israel, and Norton Mezvinsky. Jewish Fundamentalism in Israel. London and Sterling, VA: Pluto Press, 1999. 
Sheleg, Yair. The Political and Social Ramifications of Evacuating Settlements in Judea, Samaria, and the Gaza Strip: Disengagement 2005 as a Test Case [Hebrew]. Jerusalem: Israel Democracy Institute, 2007.

Shenhav, Yehouda, and Yael Berda. "The Colonial Foundations of State of Exception: Juxtaposing the Israeli Occupation of Palestinian Territories with Colonial Bureaucratic History." In The Power of exclusive inclusion: Anatomy of Israeli Rule in the occupied Palestinian Territories, edited by Adi Ophir, Michal Givoni and Sari Hanafi, 337-374. New York, NY: Zone Books, 2009.

Shor, Eran. "Utilizing Rights and Wrongs: Right-Wing, The "Right" Language and Human Rights in the Gaza Disengagement." Sociological Perspectives 51, no. 4 (2008): 803-826.

Susskind, Lawrence, Hillel Levine, Gideon Aran, Shlomo Kaniel, Yair Sheleg, and Moshe Halbertal. "Religious and Ideological Dimensions of the Israeli Settlements Issue: Reframing the Narrative?" Negotiation Journal 21, no. 2 (2005): 177-191.

Swedberg, Richard. Interest. Berkshire: Open University Press, 2005.

Swedenburg, Ted. "The Palestinian Peasant as National Signifier." Anthropological Quarterly 63, no. 1 (1990): 18-30.

Taub, Gadi. The Settlers and the Struggle over the Meaning of Zionism. New Haven, CT: Yale University Press, 2010.

Tilly, Charles. Contentious Performances. Cambridge and New York: Cambridge University Press, 2008.

Tilly, Charles, and Sidney Tarrow. Contentious Politics. Boulder, CO: Paradigm Publishers, 2007.

Torpey, John C. Making Whole What Has Been Smashed: On Reparations Politics. Cambridge, Mass.: Harvard University Press, 2006. 
Velthuis, Olav. Talking Prices: Symbolic Meanings of Prices on the Market for Contemporary Art. Princeton, NJ: Princeton University Press, 2005.

Vinitzky-Seroussi, Vered, and Eyal Ben-Ari. "'A Knock on the Door": Managing Death in the Israeli Defense Force." The Sociological Quarterly 41, no. 3 (2000): 391-411.

Wherry, Frederick F. Global Markets and Local Crafts: Thailand and Costa Rica Compared. Baltimore: Johns Hopkins University Press, 2008.

Williams, David R., and Chiquita Collins. "Reparations: a Viable Strategy to Address the Enigma of African American Health." American Behavioral Scientist 47, no. 7 (2004): 977-1000.

Zelizer, Viviana. Economic Lives: How Culture Shapes the Economy. Princeton, NJ: Princeton University Press, 2010.

—. Pricing the Priceless Child: The Changing Social Value of Children. New York, NY: Basic Books, 1985.

Zertal, Idith, and Akiva Eldar. Lords of the Land: The War over Israel's Settlements in the Occupied Territories 1967-2007. Translated by Vivian Eden. New York, NY: Nation Books, 2007.

\footnotetext{
${ }^{1}$ By the end of 2004, the total Jewish residents of Judea, Samaria and Gaza Districts estimated by the Israeli Central Bureau of Statistics (2005, Table 2.7) were 238,300 in 139 settlements, excluding the Jewish-Israeli residents of the disputed areas of East Jerusalem.

${ }^{2}$ Some of the meetings, especially those concerned with the compensation of business owners, were held in sub-committee forums, which were typically attended by 5 to 10 members of the full committee.
} 
${ }^{3}$ Because the committee represented much of the Israeli political spectrum, the dilemma regarding the commensuration process was also expressed by committee members themselves when criticizing the bill or other members for their insensitivity.

${ }^{4}$ All quotes from Hebrew sources (including the committee proceeding) were translated by the author. 